\title{
E-literacy in Indonesian Society Regarding Covid-19
}

\author{
Zata Ismah ${ }^{1}$, Andini Nur Bahri ${ }^{2}$, Irna Khairani Siregar ${ }^{1,}$ Dhyta Taniya Abdika Pane ${ }^{1}$, \\ Suhendri ${ }^{3}$ \\ ${ }^{1}$ Faculty of Public Health, UIN Sumatera Utara, Medan, Indonesia \\ ${ }^{2}$ Faculty of Da'wah and Communication, UIN Sumatera Utara, Medan, Indonesia \\ ${ }^{3}$ Faculty of Religion, Universitas Dharmawangsa, Indonesia \\ Email Corresponding author: zataismah@uinsu.ac.id
}

\begin{abstract}
During the Covid-19 pandemic, it is very necessary to carry out $e$-literacy because in addition to the spread of the Covid-19 virus the community was also faced with a lot of false information that was widespread on social media. One way that can be done to break the chain of spreading hoaxes is the skill of $e$ literacy. The aim of this study is to describe the access to e-literacy in Indonesian society regarding the Covid-19 vaccine. The research method used is descriptive with a cross sectional design, the study population is the Indonesian people as many as 2,759 people. Sources of data is primary data were obtained from questionnaires. The data analysis technique used descriptive statistics. Based on the results of the analysis in this study, the respondents responded related to e-literacy covid future pandemic-19, respondents stated the most difficult using information about the vaccine virus that find on the internet for the other (14.9\%); difficulty making health decisions based on information from the Internet. Meanwhile (31.4\%), it is easy to apply information from the Internet about the Covid19 Vaccine $(49.3 \%)$. And it is very easy to find information about the corona virus vaccine on the Internet (48.3\%). Overall, the Indonesian people already understand the importance of e-literacy related to the Covid-19 pandemic. The public can already judge the good or bad information they get and can decide which information to absorb to protect themselves from the threat of Covid-19.
\end{abstract}

Keywords: E-literacy, Hoax, Covid-19 Pandemic.

\section{INTRODUCTION}

The Director General of WHO in his remarks at the World Security Conference in Munic, Germany on February 15, 2020, said that currently the world is not only fighting the Covid-19 Virus but also fighting the spread of conspiracy theories that encourage misinformation about the Covid-19 virus. Covid-19 which is designated as a Public Health Emergency of International Concern (PHEIC) has spread throughout the world (World Health Organization, 2020). The spread of this virus is also followed by an abundance of both accurate and inaccurate information that continues to spread in the community.

The circulation of misinformation regarding the Covid-19 vaccine has caused confusion among the public to take self-protection measures from Covid-19. This is further exacerbated by the rate of information dissemination that is so fast and easy in line with the massive use of social media. Social media makes it easy for anyone to create, edit, delete, retrieve and distribute information so that it can cause the accuracy of the information to be unclear (Nurislaminingsih, 2020). In Indonesia, from January to August 2020 there have been 1,028 fake information (hoaxes) related to Covid-19 circulating on various social media including Facebook, Twitter, Instagram, and YouTube (Ministry of Communication and Informatics, 2020).

The amount of information hoaxes is spread in the media of social related Covid19 led to the importance of improving understanding of all information obtained by implementing e-literacy. According to (Sutrisna, 2020) social media users who understand reading and writing do not necessarily have the ability to do e-literacy. Therefore, researchers 
are interested in discussing research on the description of e-literacy attitudes in Indonesian society related to Covid-19.

\section{METHOD}

\section{Design Study}

This study is an observational study with a cross sectional design, which aims to describe the attitude of $e$-literacy in Indonesian society regarding Covid- 19.

\section{Population and Sample}

The populations of this study were all Indonesians covering all 34 provinces, with a sample size of 2759 samples.

\section{Place and time of research}

This research was conducted by researchers in Medan City, North Sumatra Province, Indonesia and research begins in 2020 .

\section{Data Collection Techniques}

The technique of collecting data on the sample was carried out by accidental sampling technique, using a research instrument in the form of a questionnaire that was integrated with online google form, then the google form link was spread through social media ( Facebook Instagram, twitter) and media chat (SMS WhatsApp), research respondents were only can fill in 1 (one) time the form (after setting the filling limit), and the respondent agrees to fill in the form by filling in the approval menu that has been designed.

\section{Data Analysis}

In this study, the data were analyzed using the frequency distribution of each variable. The variables are how easy it is to find information about the corona virus vaccine on the Internet, how easy it is to judge information (facts or hoaxes) circulating on the Internet about the corona virus vaccine, how easy it is to convince oneself to apply the information obtained from the Internet about the corona virus vaccine, how easy it is too easy to understand about the corona virus vaccine from the Internet, how easy it is to decide how to protect yourself with the corona vaccine based on information from the internet, how easy is it to use information about the corona virus vaccine on the internet for others, how easy it is to make decisions about personal health based on information from the internet about usage the corona virus vaccine, how easy it is to know where to find information about the corona vaccine on the internet, how easy is it to understand the use of the internet to answer questions about the pros and cons of using the corona vaccine, and how easy it is to find sites that can believed about the corona vaccine. 


\section{RESULTS}

The results of the research that have been carried out show the following values.

Table 1. Characteristics of Respondents

\begin{tabular}{lrrrr}
\hline & Frequency & \% & 95\% CI & \\
\cline { 2 - 5 } & & & Lower & Upper \\
\hline Gender & & & & \\
Man & & & 33.8 & 37.3 \\
Women & 982 & 35.6 & 62.7 & 66.2 \\
Total & 1776 & 64.4 & 100.0 & 100.0 \\
\hline Last education & 2758 & 100.0 & 0.1 & \\
SD & & & 4.7 & .5 \\
Junior High & 7 & 0.3 & 51.9 & 55.7 \\
High school & 155 & 5.6 & 38.3 & 42.0 \\
College & 1486 & 53.9 & 100.0 & 100.0 \\
Total & 1107 & 40.1 & & \\
\hline Marital status & 2758 & 100.0 & 86.9 & 89.4 \\
Single & & & 0.1 & 0.5 \\
Divorced & 2434 & 88.3 & 0.0 & 0.3 \\
Death divorce & 8 & 0.3 & 10.1 & 12.6 \\
Marry & 4 & 0.1 & 100.0 & 100.0 \\
Total & 312 & 11.3 & & \\
\hline
\end{tabular}

Based on Table 1. The respondents of this study were mostly female. Most education is at the high school level. Most of the marital status is not yet married.

Table 2. Respondents Information Sources

\begin{tabular}{lcccc}
\hline Variable & Frequency & $\%$ & \multicolumn{2}{c}{ 95\% CI } \\
& & & Lower & Upper \\
\hline Facebook & 86 & 3.1 & 2.5 & 3.8 \\
Instagram & 1050 & 38.1 & 36.2 & 39.9 \\
Newspaper & 18 & .7 & .4 & 1.0 \\
Magazine & 2 & 0.1 & 0.0 & 0.2 \\
Official Website & 260 & 9.4 & 8.3 & 10.5 \\
Radio & 6 & 0.2 & 0.1 & 0.4 \\
TV & 725 & 26.3 & 24.6 & 27.9 \\
Twitter & 510 & 18.5 & 17.0 & 20.0 \\
\hline
\end{tabular}

From Table 2, it can also be seen that the sources of information that respondents often receive are also varied and the most come from social media applications, namely Instagram as much as $38.1 \%$ and electronic media, namely $\mathrm{TV}$ as much as $26.3 \%$. 
Table 3. Health Literacy which is Very Difficult to Access Related to the Covid-19 Virus Vaccine

\begin{tabular}{|c|c|c|}
\hline Variable & n & \% (Lower-Upper 95\%) \\
\hline \multicolumn{3}{|l|}{ Most Very Difficult Answers are } \\
\hline $\begin{array}{l}\text { - in Using information about the Covid-19 Vaccine } \\
\text { to convince others (A6) }\end{array}$ & 402 & $14.9(13.5-16.2)$ \\
\hline $\begin{array}{l}\text { - Knowing reliable sites about the corona vaccine to } \\
\text { help one's own health (A10) }\end{array}$ & 325 & $11.8(10.6-13.0)$ \\
\hline \multicolumn{3}{|l|}{ Most Difficult Answers are } \\
\hline $\begin{array}{l}\text { - Making health decisions based on information from } \\
\text { the Internet (A7) }\end{array}$ & 866 & $31.4(29.7-33.1)$ \\
\hline $\begin{array}{l}\text { - Understand the use of the internet to answer } \\
\text { guestions about the pros and cons of using the }\end{array}$ & 722 & $26.1(24.5-27.8)$ \\
\hline Covid-19 vaccine (A9) & 683 & $24.8(23.2-26.4)$ \\
\hline \multicolumn{3}{|l|}{ - Judging Facts or Hoaxes (A2) } \\
\hline \multicolumn{3}{|l|}{ Most Easy Answers are } \\
\hline $\begin{array}{l}\text { - Applying information from the Internet regarding } \\
\text { the Covid-19 Vaccine (A3) }\end{array}$ & 713 & $49.3(48.2-51.4)$ \\
\hline $\begin{array}{l}\text { - Deciding how to protect yourself with vaccines } \\
\text { based on information from the Internet (5) }\end{array}$ & 203 & $45.4(43.5-46.3)$ \\
\hline $\begin{array}{l}\text { - Understanding the Covid-19 Vaccine on the Internet } \\
\text { (A4) }\end{array}$ & 743 & $45.7(44.1-46.3)$ \\
\hline \multicolumn{3}{|l|}{ Most Very Easy Answers are } \\
\hline - Find information about the Covid-19 Vaccine & 1333 & $48.3(47.2-49.7)$ \\
\hline $\begin{array}{l}\text { (A1) } \\
\text { - Knowing where to find information (A8) }\end{array}$ & 701 & $25.4(24.5-26.8)$ \\
\hline
\end{tabular}

Based on Table 2. it can be seen the respondents' answers related to e-literacy covid future pandemic-19 respondents answered the most difficult using information about the vaccine virus corona that find on the internet for the other (14.9\%); difficulty making health decisions based on information from the Internet. Meanwhile (31.4\%), it is easy to apply information from the Internet about the Covid-19 Vaccine (49.3\%). And it is very easy to find information about the corona virus vaccine on the Internet $(48.3 \%)$.

\section{DISCUSSION}

Easy access and dissemination of information the era of digitalization has made Indonesia technology literate, but besides those various crimes have emerged such as hoaxes, fake news and hate speech committed by irresponsible people (Pakpahan, 2020). The Covid-19 pandemic is the most widely circulating issue in society. From hoax news circulating in the community 1/3, it is about the Covid-19 pandemic hoax (Kominfo, 2019). Based on table 2, it is known that the source of information that is often received by respondents is through social media in the form of Instagram. Information about the use of media in the community is important to see whether people are exposed to hoax information or not. The results of research conducted by MASTEL (2017) mentions that the channels are widely used in the deployment of a hoax is a website, amounting to $34.90 \%$, the chat application (WhatsApp, Line, Telegram) amounted to $62.80 \%$, and through social media (Facebook, Twitter, Instagram, and Path) which 
are the most used media, reaching $92.40 \%$ ). This means that respondents in this study can be estimated that few are exposed to false news or hoaxes.

Judging from the research data, based on several questions in table 3. The general public is not difficult to get information about Covid-19. This is estimated because most respondents use Instagram social media. According to Letuna (2021), it was found that Instagram was the best educational media in the covid-19 vaccine. In table 3 , it is also known that respondents tend to more easily trust information spread over the internet and feel confident in using the information. Basically, the user behavior more likely to believe a hoax information if the information is in accordance with the opinions or attitudes that are owned (Respati, 2017). Feeling positive will arise in ourselves someone if opinion or belief gained recognition and likely will not care whether the information received is correct or incorrect. They will redistribute the information without any filters. This condition is exacerbated if the hoax information spreader has insufficient knowledge in utilizing the internet.

The role of the community in fighting fake news or hoaxes is very important because when viewed from the way hoaxes work to the community, it starts with three key elements, namely perception, mindset, and mental health. These three key elements will produce behavior (Ratih Ibrahim, 2019: 24). So, the key is how to combat hoax namely the establishment of a good mindset and healthy that will create the perception that the positive and ultimately result in people who have mental are healthy and strong to develop. It is in line with the objective's literacy media is to produce citizens of the community were "well informed" and can make the assessment of the content of media based on their knowledge and understanding of the media is concerned (Eadie, 2009: 564). Through the development of media literacy studies, it is hoped that the public will be able to distinguish between useful media content and those that cause harm or loss to their lives.

\section{CONCLUSION}

Based on the results of the analysis in this study, it shows that the Indonesian people already understand the importance of e-literacy related to the Covid-19 pandemic. The public can already evaluate the good or bad information they get and can decide which information to absorb to protect themselves from the threat of Covid-19. Digital literacy not only invites people to read but also can analyze all the received information so that people will always be able to not consume hoaxes.

\section{ACKNOWLEDGMENTS}

Acknowledgments researchers to respondents who are the people of Indonesia who have contributed so that this research can work well and is able to be written in this article.

\section{REFERENCES}

Chumairoh, H. (2020). The Threat of Fake News Amid the Covid-19 Pandemic. Vox Populi, 3 (1), $22-30$

Gumgum, G., Justito, A., \& Nunik, M. (2017). Media Literacy: Smartly Using social media in Tackling Fake News (Hoax) by High School Students. Community Service, 1 (1), 35-40.

Ministry of Communication and Informatics. (2020). A total of 1,028 Hoax Noting Kominfo Scattered Related Covid-19. Retrieved September 7, 2020, from https://kominfo.go.id/content/detail/28536/kominfo-mencatat-sebanyak-1028- 
hoaks- spread-related-covid-19/0 /

highlight_media

Letuna, MAN (2021). Instagram as a Covid-19 Vaccine Educational Media in Indonesia. Journal of Communio: Journal of the Department of Communication Sciences, 10 (1), 88-106.

Nurislaminingsih, R. (2020). Knowledge Service about COVID-19 at the Information Institute. Tik Ilmeu: Journal of Library and Information Science, 4 (1), 19-38

Pakpahan, Roida, and YuniFitriani. "Analysis of the use of information technology in distance learning in the midst of the corona covid-19 virus pandemic." Journal of Information Systems, Applied, Management, Accounting and Research 4.2 (2020): 30-36.

World Health Organization. (2020). Retrieved September 18, 2020, from htt ps: //www.who.int/news - room / feature-stories / detail / immunixing-the-publicagainst- misinformation 